TITLE:

\title{
Viscosity Changes in the Cytoplasm during Mitosis as Indicated by Brownian Movement
}

$\operatorname{AUTHOR}(\mathrm{S}):$

Kato, Kazuo

\section{CITATION:}

Kato, Kazuo. Viscosity Changes in the Cytoplasm during Mitosis as Indicated by Brownian Movement. Memoirs of the College of Science, Kyoto Imperial University. Ser. B 1933, 8(2): 201-215

ISSUE DATE:

1933-01-31

URL:

http://hdl.handle.net/2433/257780

RIGHT: 


\title{
Viscosity Changes in the Cytoplasm during Mitosis as Indicated by Brownian Movement
}

\author{
By \\ Kazuo KATô \\ (Botanicn! Institute, Kyoto Tmperial University) \\ (With Plates $11 L-I V$ ) \\ (Received Nov, 3, 1932)
}

The change in the viscosity of the cytoplasm that takes place during mitosis is one of the important subjects of investigation and discussion in cytology. This cliange has been studied by the method of centrifuging by HeilmeunN (1921 and 1926) and Kostorf (1930). The Brownian movement has also been taken as the indicant in this line of investigation by Treblond (1919a,b), Srifriz (1920), and Bayliss (1920), and more recently by Brinley (1928), Prixarer (1930 a, b) and Freneriske (1932). Pekarek has made use of this phenomenon for measuring absolute viscosity, adopting the method of FürTu in the investigation, and lately Frederiske has determined the absolute viscosity of the protoplasm of an amoeba with this method and compared it with the viscosity found when the amoeba was experimentally treated with some chemicals.

The writer made some observations of the Brownian movement in pollen mother cells with a view determining the relative changes in the viscosity taking place during mitosis. Observations were also made in somatic cells for comparison. They were both macle during the summer in 1929 and 1930 .

Before going further the writer wishes to acknowledge his inclebtectness to Prof. Y. Kuwada for his kind suggestions and criticism during the course of the investigation. 


\section{Material and method}

In pollen mother cells in the Lilizm species there are many granules (cytosomes) of a fat-like nature which stain red with Suclan III and black with a 2 per cent. solution of osmic acid. They are of various sizes, but all spherical in shape, and exhibit the Brownian movement in the living cytoplasm. In the present investigation $L$. speciosum was exclusively used as material for observation of pollen mother cells', and staminate hairs of Tradescantia reflexa for that of somatic cells.

The principle of the method of investigation adopted in this study is based on SvEDbrerg's formula governing the Brownian movement of a particle in a medium,

$$
A \cdot \eta=\text { constant }
$$

in which $A$ is amplitude and $\eta$ viscosity. The viscosity is thus inversely proportional to the amplitude. To obtain the relative magnitude of the amplitude or the extent of movement of a granule, its image was projected and plotted on section paper at the level of the microscope stage by means of an ABBE's camera lucida every 5 seconds for 2 minutes, except where otherwise indicated. In the case where the viscosity was so high that the granules could move only to a small extent, the duration of the observation was limited to a shorter period of time than 2 minutes in order to avoid confusion of the points plotted. The relative viscosity change at various stages was determined by comparing the relative extents or magnitudes of the movement of the granules thus obtained, i. e. the areas covered by the plotted points.

If a granule lies very near the cell surface or the nuclear membrane, or has another granule within its "sphere of action", the Brownian movement undergoes a modification through collision and attraction. In the present investigation, therefore, those granules were chosen for observation which were of a certain definite size, about medium between the smallest and the largest, and which lay rather near but at a clefinite distance from the cell surface, having no other granule within their sphere of action. These granules are called "standard granules" in the present paper.

The movement of granules smaller or larger than the standard granules was also taken into consideration. In case the determination of the stage of mitosis was clifficult in the living state, it was made at the end of the observation by staining the material with aceto-carmine.

I. In the observition in 1930 , it was often noticed that exceedingly voluminons granules were present mingled with smaller ones of various sizes. In 1929 these large gramules were found only towards the end of the flowering season.

2. Amminatmen's Handb. d. biol. Arbeitsmethoden, Abt. II, Teil 2. 
The observations were made in a room at a practically constant temperature, about $25^{\circ} \mathrm{C}$, so as to make the error due to change in temperature as little as possible (cf. F. and G. Weber, rgr $;$ F. Weber and H. Honfenegger, 1923). For observation of pollen mother cells pollen sacs of a young anther were cantiously cut at one end with a sharp knife and the pollen mother cells were gently forced out of them together with the anther slime on a slicle glass. An artificial medium was not used. A Zisiss immersion lens $1 / \mathrm{r} 2$ ancl compensation ocular 12 were usecl.

\section{Observation}

\section{Pollen mother cells in Lilium speciosum}

\section{Preliminary observations}

Before entering on our main subject, it is necessary to give a brief account of some peculiarities noticed cluring the observation of pollen mother cells. In stages prior to the synizesis, they are closely packed together in the pollen sac and are angular in shape. During the synizesis and the following stage of open spireme, they become round in shape and separated from one another. As is usually the case, the nucleus appears as an opaque body embedded in the cytoplasm, which contains many granules that exhibit the Brownian movement. The nucleolus appears as a dull droplet in the nucleus, being round in shape usually, except in the early stage of prophase, when it is not infrequently lens-shapec.

At the first moment of observation under the microscope, the nucleus is usually seen as a homogeneous opaque body, but it gradually shows some inner structure. The details of the structure, however, owing to the fact that the difference between its refractive index and that of the karyolymph is too small, can not be discriminated so clearly and distinctly as in fixed materials. When the observation is further continued under the microscope, the nucleus becomes again opaque graclually and its inner structure fades away from sight. When the cells are subjected to still longer observation, small vacuoles appcar in the cytoplasm, which grow larger and become conffuent with one another. This is a sign of degeneration, as has been noted by a number of authors.

Transient stoppage of the movement of the granules is ... observed at times, which is followed by a sudden reactivation of the movement. 
This phenomenon has been noticed by Evart (1903), Gaidukov (1910), Prenarek (rgzo a) and others, and is regarded by these authors as a symptom of protoplasm degeneration. A considerable degree of secming plasmolysis (pscudoplasmolysis) is also observed (cf. Yamnna, 1926), though not frequently, and then the granules appear quite motionless. In fixed material we sometimes find pollen mother cells diffusely stained. They seem to be those cells which had displayed psendoplasmolysis in their fresh state.

When a pollen mother cell is ruptured at a point, the granules in the cytoplasm exhibit more active Brownian movement than those in the neighbouring intact cells, presenting a clear contrast to the latter. And also, if a cell is crushed under the cover glass by pressing it, the granules excluded into the anther slime are seen to manifest more active movement than in the cell.

It is very important in determinations of the viscosity of the protoplasm to discriminate whether the material under observation is in the normal healthy condition or not. This is not such a difficult task, however, if one is thoroughly familiar with the peculiarities mentioned above, although other necessary precautions not mentioned here must of course also be taken.

\section{Brownian movement}

Loptotene-symizesis. In stages prior to the synizesis the standard granules exhibit a slow rotatory movement, presenting a simmering appearance as they rotate. Even the granules smaller than the standard ones appear not to show any vibratory movement. In the stage just before the synizesis, when the nucleus suddenly grows voluminously but has the nuclear threads still evenly distributed in it, the standard granules show a combination of movements, rotatory and vibratory. This stage is met rather rarely, and it seems likely that it is of very short. duration and is immediately followed by the next stage, the synizesis.

Symizsis. The nuclear threads are distributed on one side of the nucleus, but the granules in the cytoplasm are evenly distributed (Fig. r). The standard granules generally show a rotatory movement in this stage, although there are not seldom found some showing a combined movement of rotation and vibration with a comparatively large amplitude, as is shown in Fig. 7 .

Pachytine. In this stage the standard granules exhibit a vibratory movement to the extent shown in Fig. 8. Granules larger than the 
standard ones show a combination of vibration and rotation, while smaller ones show a clancing or a rather active Brownian movement.

Strepsitine and second contraction. In the strepsitene stage, the standard granules show Brownian movement of a narrow extent without any fixed direction (Fig. 9). They are found in almost the same state of movement in the next stage, that of the second contraction, also (Figs. 2 and Io).

Diakmesis. The nucleus attains its maximum volume in this stage and almost all the granules are forced to cluster around the nucleus. They are, therefore, clense in distribution in the neighbourhood of the nucleus and thinner towards the periphery of the cell (Fig. 3). Those near the nucleus are generally found motionless, though there are among them some granules rotating or showing a rotatory movement accompanied by vibration. Those near the periphery of the cell or the cell surface show, on the other hand, Brownian movement of a narrow extent (Fig. I I). From these local variations in the extent or magnitude of the movement we see that a less fluid condition is pronounced in the vicinity of the nucleus, and the fluidity becomes gradually greater as the periphery of the cell is approached.

Third contraction. When the nuclear membrane disappears, the chromosomes come nearer one another to form a more or less compact group in the central region of the cell leaving a spherical zone free from granules around the group-the third contraction. This spherical homogeneous hyaline area is also observed in metaphase and anaphase outside the spindle area. Associated with the disappearance of the nuclear membrane another remarkable phenomenon is observed which was first noticed by Sakamura $(1927)$ in pollen mother cells in Lilimm concolor. This is the aggregation of the cytosomes or granules in the cytoplasm. It is observed to take place also in L. tigrimm. In these plants, however, there are found some granules which remain in the single state. These single granules appear at first sight to be motionless, but closer observation reveals that they are moving with a slow rotatory movement, which may be accompanied by vibration at some intervals of time.

Metaphase. The chromosomes forming the central group rearrange themselves into the nuclear plate. Aggregates of granules consisting of ten or so granules each are also observed in this stage as in the third contraction stage (Fig. 4). Some single granules free from aggregation are also found. In the metaphase, in which the chromosomes are armanged in one plane, no perceptible difference is found in 
the mode of movement of the single granules from that observed in the third contraction stage. When, however, the process of division proceeds and the chromosome separation is about to begin, the single granules show an active Brownian movement of a somewhat large extent (Fig. I 2). The aggregates of granules also exhibit an active dancing movement in this stage.

Anaphase. The aggregation of granules does not entircly disappear in the anaphase, but becomes gradually less pronounced as the division proceeds. The process of the loosing of the granules from aggregation is observed under the microscope. While in the metaphase the aggregates of granules are uniformly found without any localization in the cell, in the anaphase, especially in the late anaphase, they are only conspicuous in the vicinity of the equatorial region, being now less marked in the polar region. Fig. I 3 shows an example of the movement of a single granule in anaphase. The extent of the movement varies in places. In some cases, a translational movement of granules is observed along the cell surface towards the pole. In the course of this movement the granules often exhibit a zigzag movement which is followed again by the translational movement. This latter movement of the granules is probably due to the movement of the cytoplasm. We also often come across a case where scarcely visible tiny particles found at the poles exhibit such an active and quick Brownian movement that it is impossible to follow the direction of their movement.

Telophase. The aggregation of granules is lost almost entirely at about the time when the daughter nuclei are furnished with a new membrane. Most of the granules are now single and evenly distributed in the cytoplasm. The movement of the standard granule in this stage is recorded in Fig. I4.

Interkinesis. In the interkinesis, almost all the granules undergo a rearrangement so that they gather in two rows on both sides of the newly formed separating wall. This behaviour of the granules is the same as that of starch grains during interkinesis observed by MaNN (1924) in Ginkgo bilobe and by Kuvada (r929) in Cycas rcaluta. Figs. Is and if show the range of the movement of the standard granules in this stage, when the granules exhibit a vibratory movement.

Homotyp metaphase. During the period from the interlinesis down to the moment of the disappearance of the nuclear membrane in the homotype division, the behaviour and movement of the granules 
is almost the same as in interkinesis, no discernible difference being found among these stages. When the nuclear membrane has disappeared, however, the aggregation of granules occurs again as in the heterotype metaphase (Fig. 5). Some unaggregated granules are also found, and they show an active Brownian movement of almost the same range as that observed in the heterotype metaphase (Fig. I7: comp. with Fig. 12). The aggregated granules are found in a state of active jostling and tremulous movement.

Homotype telophase. When the telophase is entered, the aggregation disappears and the granules, now single, are distributed evenly in the cytoplasm. They move about within relatively confined limits as recorded in Fig. $x$.

Young pollon grains: The granules are found distributed evenly in the cytoplasm, but, compared with those in the heterotype and homotype divisions they are clearly fewer in number (Fig. 6). The standard granules generally show a combination of rotation and vibration, although not seldom some of them are obscrved moving with a Brownian movement of very narrow extent.

Some noteworthy facts concerning the granule aggregation, observed in the present investigation, will be mentioned below. As described in the foregoing pages, the aggregation of granules occurs in the third contraction, metaphase and anaphase in both mitoses, heterotype and homotype, as a characteristic feature of the stages where the nuclear membrane has disappeared so that the cytoplasm may have mingled with the karyolymph. Such an aggregation may occasionally be observed also in the stages where the karyolymph and cytoplasm are distinctly separated from each other by the nuclear membrane such as in the open spireme, diakinesis and tetrad, it being observed much oftner in the diakinesis than in the other stages. The aggregation, however, takes place in these stages to a much lesser extent than in those stages where the nuclear membrane has entirely disappeared, both the aggregations and their constituent granules being very much reduced in number. In synizetic nuclei we sometimes come across a case where the nuclear membrane is accidentally ruptured so that the karyolymph comes directly in contact with the cytoplasm. In this case some granules occasionally happen to enter into this ruptured nucleus and exhibit an active Brownian movement in it (Figs. 20 a, b). This gives an idea of the highly liquid nature of the karyolymph as compared with the surrounding cytoplasm, although it must be considered that this highly liquid state may in part be due to deterioration 
of the karyolymph caused by the rupture of the nuclear membrane. After a few minutes some of these granules aggregate in groups which present a tremulous movement. At this time, granules found outsido the nucleus also form aggregations which move tremulously.

When the cell wall is ruptured and the contained granules are thrown out into the slime sap of the anther, they exhibit an active Brownian movement of a wider range than in the cell (Figs. 2 i a, b). This movement shows that the slime sap is less viscous than the cyotoplasm in the pollen mother cells. The granules form no aggregation at all in the slime sap of the anther.

\section{Staminate hairs of Tradescantia reflexa}

Observations were made in a medium consisting of a 3 per cent. cane sugar solution. In this material there are found in the cytoplasm no granules of a size suitable for accurate observation of their movement, but numerous minute microsomes which exhibit a Brownian movement. In the present study the movement of these microsomes was investigated.

In cells in prophase in the apical part of the hair, the microsomes show a Brownian movement of a narrow range. In the meta-anaphase stage where the sister chromosomes are just separating from each other, they exhibit an active Brownian movement of a wider range. No such aggregation as that found in the case of the granules in pollen mother cells is found in this case of microsomes throughout all the stages of mitosis. When the division reaches the interphase stage, the movement of the microsomes seems to be less active.

Mitotic figures are usually found in cells situated in the apical part of the hair, but can not infrequently also be found in the fourth, or: fifth, and in rare cases even in the eighth cell from the tip. In a hatr consisting of 20 cells, it was observed that in the fifth cell which was dividing, and in anaphase, there appeared to exist no streaming in the cytoplasm at all, while in the two adjacent non-clividing colls on both sides of it a clear streaming movement of the microsomes was found. In other instances too, no streaming of the protoplasm could be observed in cells in the dividing state, and if there is any, it is a very inert one. This result of observation is in accord with Schuspe's observation (Schande, 192.5b). In one case, a cell in which the nucleus was in a late telophase and ovoidal in shape was subjected to long obscrvation. In this cell no streaming movement of microsomes was found at the beginning of the observation. After about an hour the nucleus 
Was of spherical shape and in the "resting." stage, and the streaming movement of the microsomes was then evident along the periphery of the vacuoles. Generally, the streaming is more prominent in a cell near the basal part of the hair, and division figures are not found in cells in which the cell sap is coloured purple.

\section{Discussion}

From his observation of the Brownian movement in various matetials, Leblond ( $19 \mathrm{I} 9 \mathrm{a}, \mathrm{b}$ ) reached the conclusion that the protoplasm is generally of a more fluid consistency in its active state, such as in division and fertilization. This phenomenon of liquefaction taking place cluring the activity of the cell is recognized by many authors.

In the observations described above, it has been shown that in pollen mother cells of Litium speciosum there are marked periodic changes in the cytoplasmic viscosity during mitosis, both heterotype and homotype, that is, a fall in the stages of late metaphase and anaphase and a rise in the following stages. Such a fall in cytoplasmic viscosity in the stage of chromosome separation can also be recognized to take place in staminate hair cells of Tradescantic reftexa. This result of observation is fairly in agreement with that obtained by Strangeways (1923) in an animal. He states that " during the process of division the granules have been in a state of active movement following from one side or other of the two protoplasmic masses." The result obtained through the centrifugal method by HimbrunN (1921) from Cumingia eggs shows that in both maturation divisions and cleavage the protoplasmic viscosity increases just before the appearance of the spindle, followed by a sharp decrease in viscosity. Generalizing the results obtained in his centrifugal experiments on pollen mother cells of Nicotian tabacum, Kos'off (1930) says that "there is an increase of CV occurring during the prophase and diakinesis followed by a decrease in the heterotype metaphase and early anaphise and another increase during the late anaphase and telophase, the same cycle being repeated in the homotype division ". SElfriz (1920) and Chan-

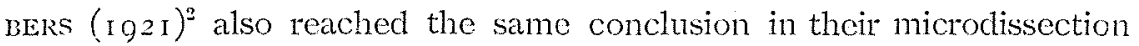
experiments, (though it must be kept in mind that the insertion of a glass needle into the cell may have caused a change in the cytoplasmic

I. $C V=$ cytoplasmic viscosity.

2. He came to the opposite c.ndusion in his first experiment (Cimmbris, 1920). 
viscosity), that there is a fall in the protoplasmic viscosity during the amphiaster stage.

The viscosity varies not only with the stages during mitosis, but also in different regions in the cell, as is clearly shown in diakinesis. In this stage a less fluid condition is pronounced in the vicinity of the nucleus and a more fluid condition in the peripheral region.

The result we obtained, that the viscosity markedly rises in the diakinesis, is in accord with the result of Ifeilbruns (1920, 1921) that the formation of the spindle is proceded by a marked increase of viscosity in the cytoplasm. But the fact that such a viscosity increase was not found in the corresponding stage in the homotype division seems to show that a generalization of this relation between the spindle formation and the increase of viscosity in the stage immediately preceding it is premature. It also scems to be worth whilo mentioning that in synizesis, where the nucleus grows markedly in volume as in diakinesis, no discornible change in viscosity was found. The principal process taking platce may be the same in these cases, but other factors peculiar to each stage might result in different phenomena. After the formation of the spindle, there occurs a conspicuous decrease in the viscosity of the surrounding cytoplasm. This seems to show that the spindle formation is related in some way or other to the marked decrease in the cytoplasmic viscosity.

Halbiruno (1921) explains the relation between the spindle formation and the viscosity decrease in the cytoplasm by the assumption that the spindle is formed as a result of coagulation of the spindle substance. The spindle appears really to be firmer in its consistency than the surrounding cytoplasm, as is seen from the fact observed in centrifugal experiments (ILllue, 1909; ANoksws, 1915) as well as cataphoresis experiments (WAKAYAMA) that the spindle is driven towards the direction of force as a complete entity, and the fact that it undergoes only a slight deformation even when it has been pushed by centrifugal force against the cell wall, as was observed by the writer himself in his unpublished experiments (1926-27). According to Scrafies (1925 a, 1929), the spindle is composed of lamellae and an intra-lammellar fluid substance, the system being of a solid nature as a whole. This view of SchaEde that the spindle is partly of a fluid nature is supported by BuLnak's observation of a few minute granules in the spindle in staminate hair cells of Tradescantio arginica. (BüLAR, 19.30), which

1. Cited from luyn (1926). 
show a more free movement along the direction parallel to the long axis of the spindle than along other directions, a fact which is equally favourable to BuLAk's view that the spindle is of a fibrous structure. We are, at present, not intending to discuss the problem further, but merely to point out here that in comection with this problem of viscosity change in the cytoplasm cluring mitosis, it is very desirable that observations of the Brownian movement in the nucleus such as those made by (Ganduor ( 1906 ) in Tradcscantia virginica, by Gross (1917) in Limnca stagnalis and by Tepseschen $(1924)$ in Oltica dioica, Ficie foba, Paramecium aurelia etc. should be made with nuclei in differont stages, if possible.

In staminate hairs of Tradescantia reflexa, no clear strcaming of the protoplasm is recognizable in the dividing cells. With regard to this phenomenon observed in Tradescantia virginica SchaEde (1 925b) states: "Das Aufhören der raschen Zirkulation lässt sich daclurch erklären, dass der Korn für scine Volumenzunahme einer Aufnahme von Flüssigkeit bedarf, dis ihm das Plasma liefern muss, und dadurch mag. es dickflüssiger und $z u$ schneller Strömung tunfähig werden." Our knowledge as to the cause of the protoplasmic streaming is, howover, meagre as yet, and we have no idea as to what causal relation exists between the stopping of streaming and the initiation of mitosis, though we may perhaps say that the former phenomenon must serve as an important clue to the study of the latter.

In Lilinm species, at least, the aggregation of fat granules is a peculiar phenomenon in the metaphase and its adjacent stages, the third contraction and early anaphase, in both heterotype and homotype divisions in pollen mother cells. This aggregation is sometimes also found in the diakinesis, and, very rarcly, "in the open spireme stage and in tetrad cells. It is also observed in the synizesis if the nuclear membrane has been ruptured accidentally. Sakamura (1927) has shown by his experiment that scattered cytosomes (called "granules" in this paper) in tetrad cells in Lilium cordifolium can be caused to form aggregations by passing $\mathrm{CO}_{2}$ gas through the medium in which the cells have been mounted, and that this agsregated condition can be brought back again to the scattered condition by replacing the $\mathrm{CO}_{2}$ gas with air free from it. From this result, he regards the change in hydrogen ion concentration as one of the causes of the cytosome aggregation. The aggregation we observed in cells with ruptured synizetic nuclei may also be regarded as due to a change in the hydrogen ion concentration in the cytoplasm caused by an injurious condition as- 
sociated with the rupture of the nuclear membrane. In the report on their micrurgical investigation made with starfish eggs, Chambers and Pollack (1927) express the view that the injury caused by repeated thrusts of a micro-needle into the cytoplasm causes cytolysis which results in the rapid production of an acid and in the lowering of the cytoplasmic pH value. The aggregation phenomenon observed in apparently intact cells with nuclei in diakinesis and the open spireme stages, and in those of young pollen tetrads may also be looked upon as clue to a change in hydrogen ion concentration in the cell, caused by a cortain unhealthy condition.

\section{Summary}

I. The viscosity changes in the cytoplasm during mitosis was studied, the Brownian movement of the granules contained in it being taken as the indicant. Pollen mother cells of Lilium speciosum were used as material for the main observation, and staminate hairs of Tradescontia reflexa for comparison.

2. In both heterotype and homotype divisions recognizable changes in viscosity are observable. In the heterotype division the viscosity increases in diakinesis as compared with that seen in the preceding stages in prophase, and pronouncedly decreases in the late motaphase and carly anaphase, this being followed by another progressive increase in the late anaphase and telophase. Similar changes are also observed in the homotype division except in the stage corresponding to diakinesis.

3. I.ocal difference in viscosity is found in diakinesis, the viscous state most markedly pronounced in the vicinity of the nucleus and gradually becoming less so as the periphery of the cell is approached. 4. When the nuclear membrane is accidentally ruptured, and some granules in the cytoplasm happen to enter into the nucleus, they move with a more active Brownian movenient than in the cytoplasm. This fact shows that the karyolymph is less viscous than the cytoplasm, but it remains undetermined whether this is the natural state or an unnatural one caused by the injury.

5. In staminate hairs of Tradescantia reflexa too, Brownian movement of microsomes is found most pronounced in metaphase and anaphase. As pointed out by SchaEde streaming of the protoplasm is not observed in the dividing cells where the spindle figure is observed.

6. In pollen mother cells the aggregation of granules, first observed 
by SAKAMURA in the heterotype metaphase and anaphase, is occasionally observed in the open spireme stage, diakinosis, and in tetrads, and also in the stage of synizesis if the nuclear membrane is acciclentally ruptured.

\section{Literature cited}

ANDRrsw, F. M. 1915. Die Wirkung der Zentrifugalkraft auf Pflanzen. Jahrb. f. wiss. Bot, Brl. 56 .

BAYIISs, W. N. I920. The proparties of colloidal system. IV. Reversible gelation in living protoplasm. Proc. Roy. Soc. London, series B, vol. gr.

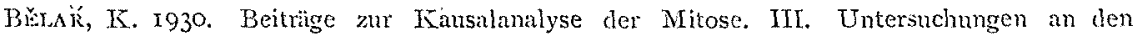
Staubharzellen und Blattmeristemzellen von Tradescantia airginica. Zeitschr. f. Zellfor. u. mikros. Anat., Bd. 10.

Briniry, F.J. 1928. The effect of chemicals on viscosity of protoplasm of amoeba as indicated by Brownian movement. Protoplasma, Brl. 4.

Cilamerrs, R. Igzo. Changes in protoplasmic consistency and their relation to coll division. Joun. Gen. Physiol., vol. 2.

Cimmmers, R. 1921. Microdissecton studies. III. Some properties in the maturation and fertilization of the echinodem egg. Biol. Bull., rol. 4.r.

Chambers, R. and Pollack, F. 1927. Micrurgical studies in cell physiology. IV. Colorimetric determination of the nuclear and cytoplasmic pH in the starfish esg. Journ. Gen. Physiol., vol. 10.

EvarT, A.J. 1903. On the plysics and physiology of protoplasmic streaming in plants. Oxford.

Frenraskre, A. M. 1932. Spontane Wiederherstellung der ursprünglichen Pritoplasmaviskosität nach Erhöhung derselben unter Einfluss von Essigsüure. Protoplasma, Bd. 15 .

Fujn, K. 1926. The rezent progres; in cytology, and methods of its investigation (Jupanesc). Rpt. Japanese Assoc. Adv. Sci., vol. 2.

Ganukov, N. rgo6. Über die utramikroskopischen Eigenschaten der Protoplasten. Ber. d. dentsch. bot. Ges., Bd. 24.

Gamukov, X. 1910. Dunkelfeldbelenchtung und Ultramikroskopie in der Biologie und in der Medizin. Jena.

GRoss, R. 19r7. Leobachtung und Versube an lebenden Zellkemen. Arch. 1. Zellfor., $\mathrm{Bd}, 14$.

Hrimnunn, I. V. 1920. An experimental study of cell division. T. The plysical conditions which detemine the appearance of the spindle in sea-nrchin eggs. Journ. Exp. Zool, vol. 30 .

Frmaunn, T.. V. I921. Protoplasmic viscosity changes during mitosis. Journ. Fxp. Zool,, vol. 34 .

HFitdrunn, L. V, ro26. The centrifugal method of detemining protoplasmic viscosity. Journ. Exp. Zool., vol. 43.

Kostow, D. r930. Protoplasmic viscosity in plants. I. Protoplasmic viscosity of dividing cclls in floral buds of tobacco. Protoplasma, Bd. I I.

KuWADA, Y. In29. Chromosome arrangement. I. Model experiments with foating magnets and some theoretical considerations on the problem. Nem. Coll. Sci. Kyoto Imp. Univ, series 3 , vol. 4 .

Lmonn, ti. Igrga. Le passige de l'état de gel ì l'etat de sol dans le protoplasma vivant. Compt. Reul. Soc. Piol., t. 82. 
I,nbrond, tE. tgrob. L'état de sol dans ses rapports avec l'activité fonctionelle du protoplasma. Compt. Rend. Soc. Biol., t. 82.

Lrepschkin, W. t924. Kolloidchemie des Protoplasmas. Berlin.

Lithr, F.R. 1909. Kanyolinetic figure; of centrifuged eggs; an experimental test of the center of force hypothesis. Biol. Bull., vol. $1 \%$.

MANn, M. C. I924. Microsporogenesis of Ginkgo biloba J. with special reference to the distribution of plastids and to cell wall formation. Univ. Call. Publ. Agr. Sci, vol. 2.

l'mkakfk, J. 1930a. Absolute Viscosititsmessung mit Hilfe der Brownschen Molekularbewegung. I. Prinzip der Methode, Voraussetzungen, Fehlerquellen der Messungen. Protoplasma, $\mathrm{Bd}$ ro.

PF⿻АREK, J. 1930 b. Absolute Viscositutsmessung mit Hilfe der Brownschen Molekularbewegung. Ir. Viscositätsbestimmung des Zellsaftes der Fpidermiszellen von Allinm cepa und des Amoeben-Protoplasmas. Protoplasina, Bd. ix.

Runsrö̈, J. 1929. Ober die Verïndernng der Plasmaliolloide bei der Entwicklungserregung des Seeigeleies. II. Protoplasma, Bd. 5.

SARAmURA, T. 1927. Chromosomenforschung an frischem Material. Protoplasma, Bd. .

Scrafne, R. r925 a. Über den Bau der Spindelligur. Beitr, z. Biol. d. Pflanzen., Bd. 14.

Scrafne, R. 1925 b. Untersuchungen über Zelle, Kern und ihe Teilung am lebenden Objekt. Beitr. z. Biol. d. Pfanzen, Bd. I4.

Scunndr, R. 1929. Die Kolloidchemie des Pflanzen Zellkernes in der Ruhe und in der Teilung. Ergebnisse d. Biol., Bd. 5.

Smirrz, W. 1920. Viscosity values of protoplasm as demonstrated by microdissection. Bot. Gaz., vol. 70 .

STrancinvays, T.S. P. 1923. Observations on the changes seen in living cells during growth and division. Proc. Roy. Soc. London, series, B, vol. 94.

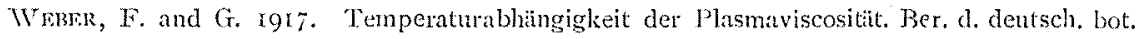
Ges., Bb. 34 .

Wannr, F, and Hombngorn, H. 1923. Reversible Viscositutserhöhung des Protoplasmas bei Käle. Ber. d. deutsct. bot. Ges., Bd. 4l.

YAMArA, G. 1926. G̈ber die Lebendbeobachung der Zellstrukturen, nebst dem Artefilit. problem in Jllanzenzytologie. Bot. Magr, rol. fo. 


\section{Explanation of Pl. III}

Figs. 1-5 are microphotographs of pollen mother cells in Lilim speciosmm, and Fig. 6 is that of pollen grains in the same plant. Magnification in all fgures: ca. $1700 \times 4 / 5$.

Fig. 1. Synizesis; showing gramules evenly distributed in the cytoplasm. A vacuole i; found in the mucleolus.

Fig. 2. Second contraction; showing the same.

Fig. 3. Dialsinesis; showing granules distributed denser in the vicinity of the nuclens than near the periphery of the cell.

Fig. 4. Heterotype metaphase; showing aggregation of granules. Note single granules found among the aggregates of gramules.

Fig. 5. Homotype metaphase; showing the aggregation of granules.

Fig. 6. Showing granules markedly diminished in number and distributed evenly in the cytoplasm.

\section{Explanation of Pl. IV}

Figs, 7-21. All figures are enlargements to $\times 4$ from the original plotting, each showing the extent of the movement in the cytoplasm except Figs. 20 and $2 \mathrm{I}$ (sce below) of a granule in the pollen mother cell in Lilim speciosmm.

Fig. 7 . Synizesis.

Fig. 8. Pachytène.

Jig. 9. Strepsitène.

Jig. ro. Second contraction.

Fig. it. Diakinesis; granule near the cell surface.

Fig. I2. Heterotype metaphase.

Fig. 13. Heterotype anphase.

Fig. I4. Heterotype telophase.

Figs. 15. and 16 . Intedinesis.

Fis. I\%. JTomo:ype metaphase.

Fig. 18. Homotype anaphase.

Fig. 10. Homotype telophase.

lïigs. $20 \mathrm{a}, \mathrm{b}$. In ruptured nuclei in synizesis.

Figs. $21 \mathrm{a}, \mathrm{b}$. In slime sup from the anther. 

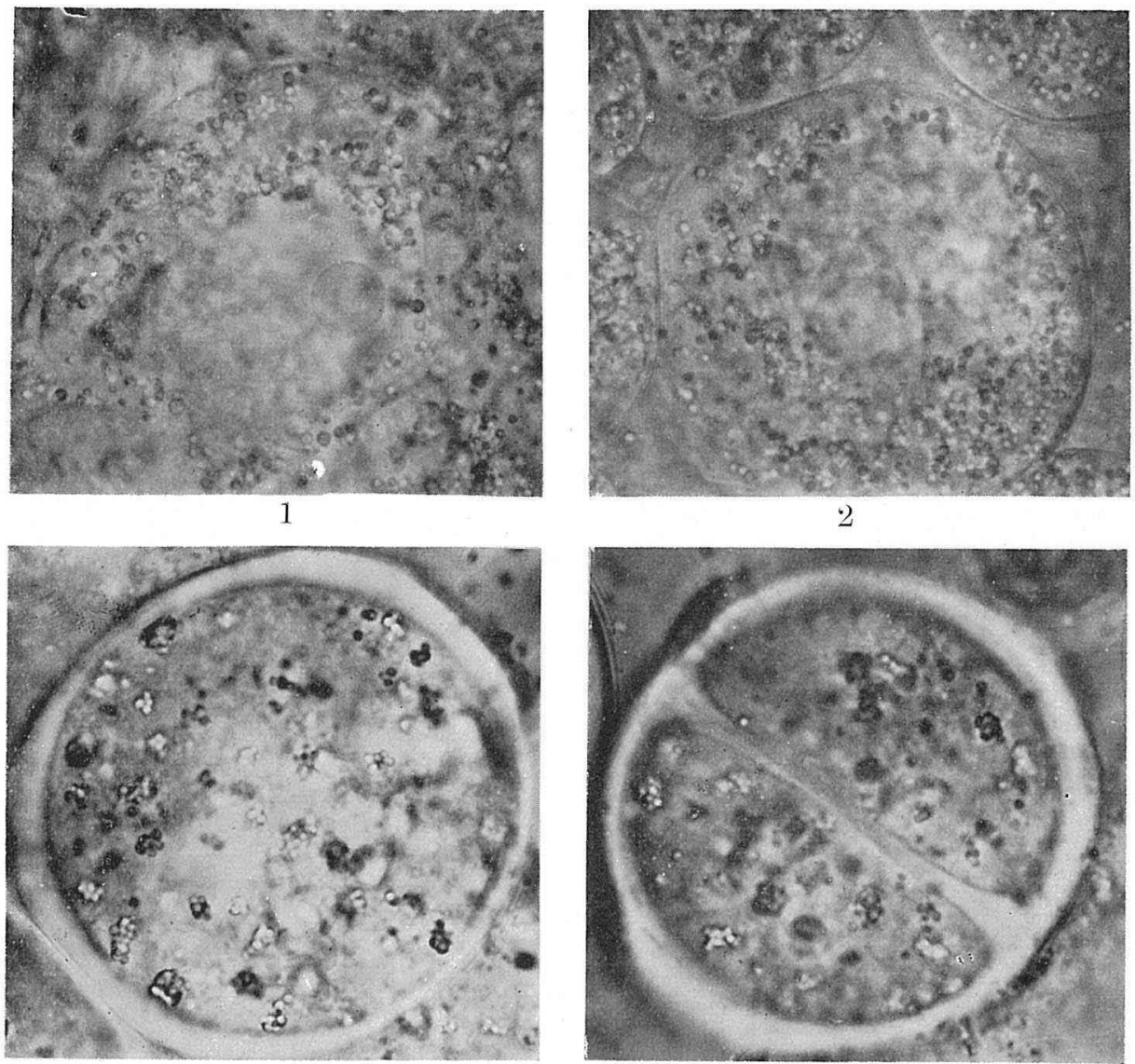

4

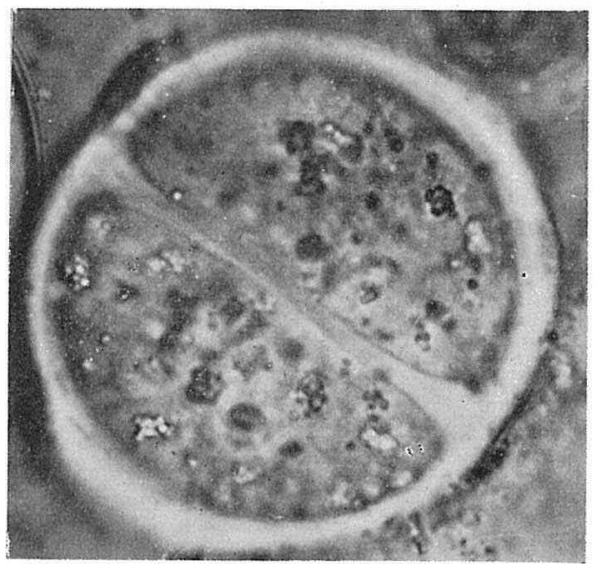

5

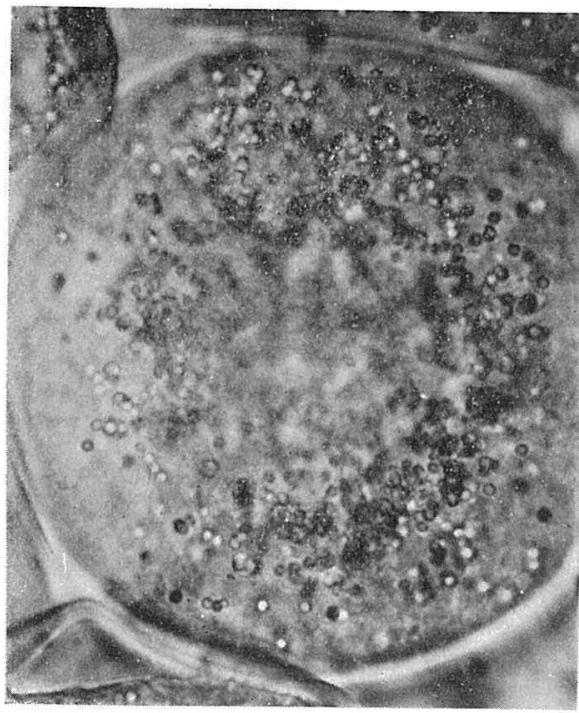

3

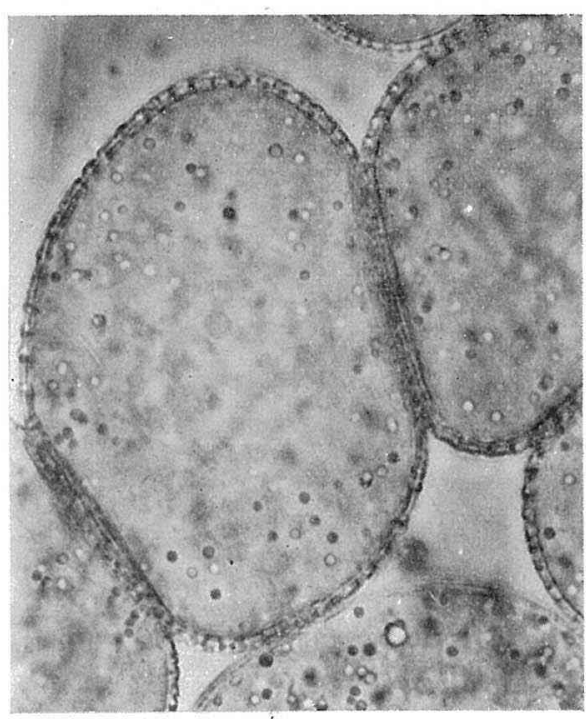

K. KATÔ 


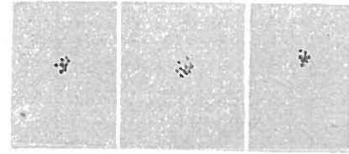

7

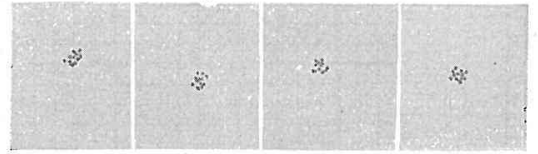

10

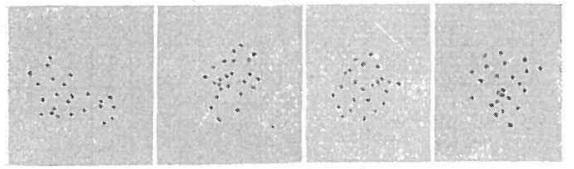

12

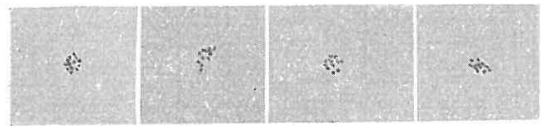

14

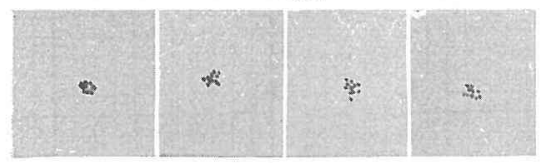

16

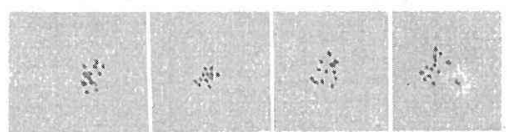

18

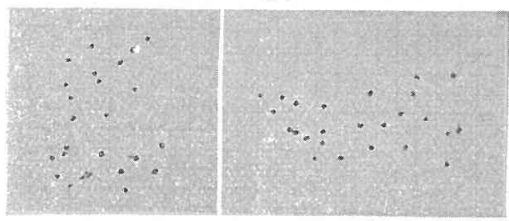

$20 \mathrm{a}$

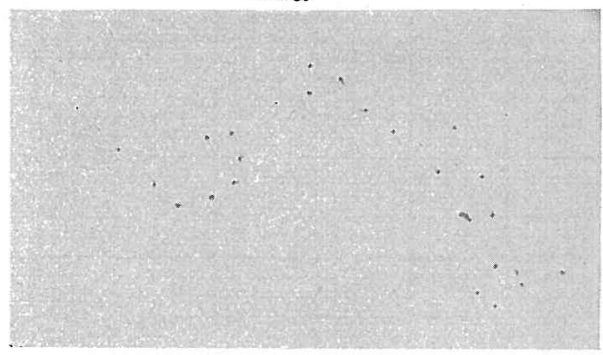

$21 a$

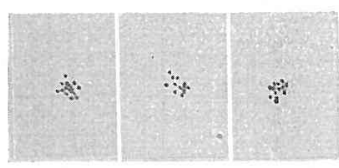

9
8

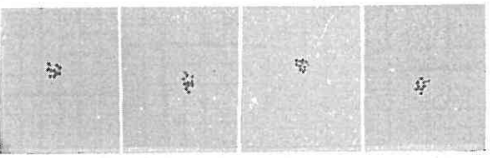

11

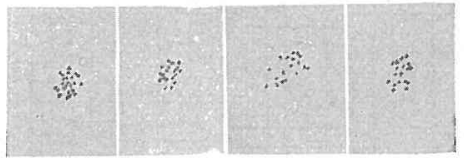

13

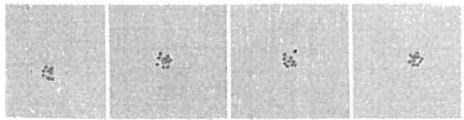

15

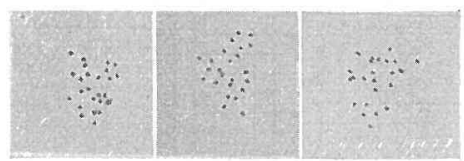

17

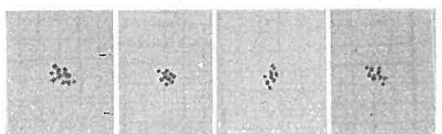

19

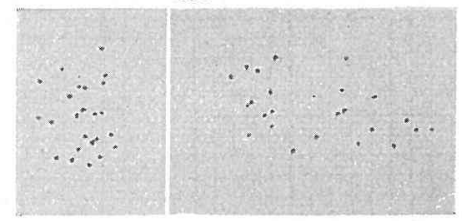

$20 \mathrm{~b}$

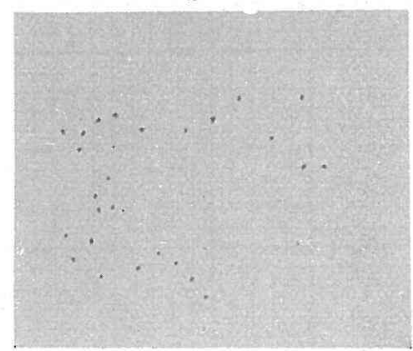

$21 \mathrm{~b}$

K. KATÔ 